\title{
Inorganic Chromium Speciation in Geothermal Water of the Podhale Trough (Southern Poland) Used for Recreational Purposes
}

\author{
Piotr Rusiniak $(0$, Katarzyna Wątor *(1) and Ewa Kmiecik® \\ Department of Hydrogeology and Engineering Geology, AGH University of Science and Technology, \\ Mickiewicza 30 Av., 30-059 Kraków, Poland; piotr.rusiniak@agh.edu.pl (P.R.); ewa.kmiecik@agh.edu.pl (E.K.) \\ * Correspondence: katarzyna.wator@agh.edu.pl
}

Received: 4 June 2020; Accepted: 1 July 2020; Published: 8 July 2020

\begin{abstract}
The results of total chromium determination (by ICP-OES method) in samples collected from nine working wells named $\mathrm{GW}_{1}-\mathrm{GW}_{9}$, exploiting geothermal water from the Podhale Trough (southern part of Poland, near the Tatra Mountains), which is used for recreational purposes, were implemented for hydrogeochemical modeling to indicate dominating chromium speciation. The reliability of the results was determined by the application of a quality assurance/quality control program, both in the laboratory and during field work. Based on chromium speciation, the risk associated with the utilization of geothermal water was calculated. The outcome showed that the concentration of $\mathrm{Cr}(\mathrm{III})$ is almost equal to the total chromium concentration $\left(1-2 \mu \mathrm{g} \cdot \mathrm{L}^{-1}\right)$. $\mathrm{Cr}_{\text {tot }}$ concentrations were also used in a health risk assessment in the case of epidermal absorption $\left(\mathrm{EDI}_{\mathrm{derm}}\right)$ during bathing in thermal pools and four assumed scenarios in relation to the handling of geothermal water. The effect of the very low $\mathrm{Cr}_{\text {tot }}$ concentration in the analyzed water on health risk calculation was estimated as low (hazard quotient value $<10^{-7}$ ). In the case of risk matrix analysis, the environmental risks were estimated as moderate, major and very severe, dependent on the assumed scenario.
\end{abstract}

Keywords: geothermal system; chromium exposure; risk assessment; environmental sciences; hydrogeochemical modeling; renewable sources

\section{Introduction}

Chromium (electron configuration: [Ar] $3 \mathrm{~d}^{5} 4 \mathrm{~s}^{1}$, sixth group, fourth period, block $d$ ) is the seventh most abundant element on Earth, residing mostly in the core and mantle; it is the 21st most abundant element in Earth's crust, with an average concentration about $100 \mu \mathrm{g} / \mathrm{g}$. The major sources of chromium in the crust are ultrabasic and basic rocks $[1,2]$.

In ground and surface water chromium occurs primarily in two oxidation states: trivalent $\mathrm{Cr}(\mathrm{III})$ and hexavalent $\mathrm{Cr}(\mathrm{VI})$. Trivalent chromium is sparingly soluble in the aqueous environment and usually binds suspended particulate matter and accumulates in bed sediments, whereas hexavalent chromium is quite soluble and more mobile. Among the trace elements present in natural water, chromium belongs to the group of elements that migrate poorly in an aquatic environment. The mobilities and concentrations of these forms are various and dependent on several parameters, i.e., geological setting, $\mathrm{pH}$, oxidation-reduction potential $\left(\mathrm{E}_{\mathrm{H}}\right)$ and the presence of $\mathrm{Fe}$ and $\mathrm{Al}$ hydroxides. In natural water at neutral and alkaline $\mathrm{pH}$, the mobility of $\mathrm{Cr}(\mathrm{III})$ is significantly limited by its adsorption on mineral surfaces. Under oxidation conditions, the major migrating forms of chromium in groundwater are anions like chromate $\left(\mathrm{CrO}_{4}{ }^{2-}\right)$ and dichromate $\left(\mathrm{Cr}_{2} \mathrm{O}_{7}{ }^{2-}\right)$. In the acidic environment and reducing conditions, the predominant species of chromium are trivalent forms such as $\mathrm{CrOH}^{2+}$ and $\mathrm{Cr}^{3+}$. 
Chromium also creates ion pairs and complexes. Ligands that may be bonded to the central atom of $\mathrm{Cr}$ can be neutral molecules (e.g., $\mathrm{H}_{2} \mathrm{O}$ and $\mathrm{NH}_{3}$ ) or anions (e.g., $\mathrm{Cl}^{-}, \mathrm{CN}^{-}, \mathrm{F}^{-}$and $\mathrm{SO}_{4}{ }^{2-}$ ) [2-7].

Chromium-bearing minerals such as chromite $\left(\mathrm{FeCr}_{2} \mathrm{O}_{4}\right)$ are generally resistant to weathering. Chromium accumulation in groundwater, lake water and deposits is also associated with anthropogenic sources, mainly the industrial processes involved in the smelting of metalliferous ores, tanneries and automotive and aerospace industries [7-10].

From the biological point of view, $\mathrm{Cr}$ is a well-known element with confirmed properties that depend on its speciation. Chromium(III) was established as an essential dietary element in the 1950s. The trivalent form is also an essential nutrient, especially for mammals, and participates in the processes of lipid and protein metabolism. It is also important for maintaining the normal glucose tolerant factor, whilst $\mathrm{Cr}(\mathrm{VI})$ has been found to be carcinogenic for internal and external organs of living organisms $[2,4,10-13]$

Due to the toxic properties of chromium, the maximum permissible concentration of this element in water intended for human consumption, $50 \mu \mathrm{g} \cdot \mathrm{L}^{-1}$, was established by the European Union in the Council Directive 98/83/EC [14] as well as in the guides published by the World Health Organization [15]. In Polish regulations [16], a maximum permissible concentration (MPC) of total chromium in drinking water is defined as $50 \mu \mathrm{g} \cdot \mathrm{L}^{-1}$, which does not deviate from the global standards. Furthermore, taking into account the actual use of the geothermal water from Podhale for heating purposes and recreational swimming pools, the quality of water provided from the circulation system has to be controlled in accordance with the proper legal regulations $[17,18]$. Water from swimming pools has to be monitored in terms of certain biological parameters, including the presence of Escherichia coli, Pseudomonas aeruginosa, Legionella and coagulase-positive staphylococci, along with and the total number of microorganisms present at the temperature $36 \pm 2{ }^{\circ} \mathrm{C}$ after $48 \mathrm{~h}$ in $1 \mathrm{~mL}$ of water. Furthermore, certain physicochemical parameters also have to be monitored, including $\mathrm{E}_{\mathrm{H}}, \mathrm{pH}$, free chlorine, bound chlorine, turbidity, chloroform, $\sum \mathrm{THM}$ /trichloromethanes (the sum of trichloromethane, bromodichloromethane, dibromochloromethane and tribromomethane), aluminum, iron, nitrates, ozone, isocyanuric acid and chemical oxygen demand $[18,19]$. In the case of total chromium, it is very important to notice that this element is not specified in Polish law regarding the physicochemical parameters of the recreational swimming pools using geothermal water. Its concentrations should be controlled because it could be released from the internal installation system if not properly flushed or from the geothermal water reservoir when the chromium-bearing minerals are present [5]. In the future, studied water could be used for drinking, among other purposes. In this scope, many tests have already been conducted in Poland, including recognition of scaling problems during geothermal water treatment processes [20-26]. The geothermal water could be also used in medicinal therapies due to the presence of specific components. Polish law specifies the threshold values for concentrations of specific components, beyond which the groundwater can be considered as potentially medicinal [27-30]. It also sets MPCs of undesirable components in excessive concentrations. The MPC for total chromium in the cases of drinking treatment or inhalation was set as $10 \mu \mathrm{g} \cdot \mathrm{L}^{-1}$. There is no regulation for the external use of water containing chromium [31]. There is a proposal to include $\mathrm{Cr}(\mathrm{VI})$ in the Third Watch List as a potential contamination risk for transitional and coastal water [32].

The objective of this study was to assess the risk related to the use of the analyzed water for recreational purposes. For this purpose, the total chromium determination in geothermal water in selected intakes from the Podhale Trough was conducted using the ICP-OES method. The next step was the geochemical modeling of chromium speciation in the geothermal water analyzed here.

\section{Materials and Methods}

Geothermal water in Podhale Trough, located in the southern part of Poland, near the Tatra Mountains (Figure 1), is captured with wells drilled at a depth from 2 to $5 \mathrm{~km}$ below surface level [33,34]. 


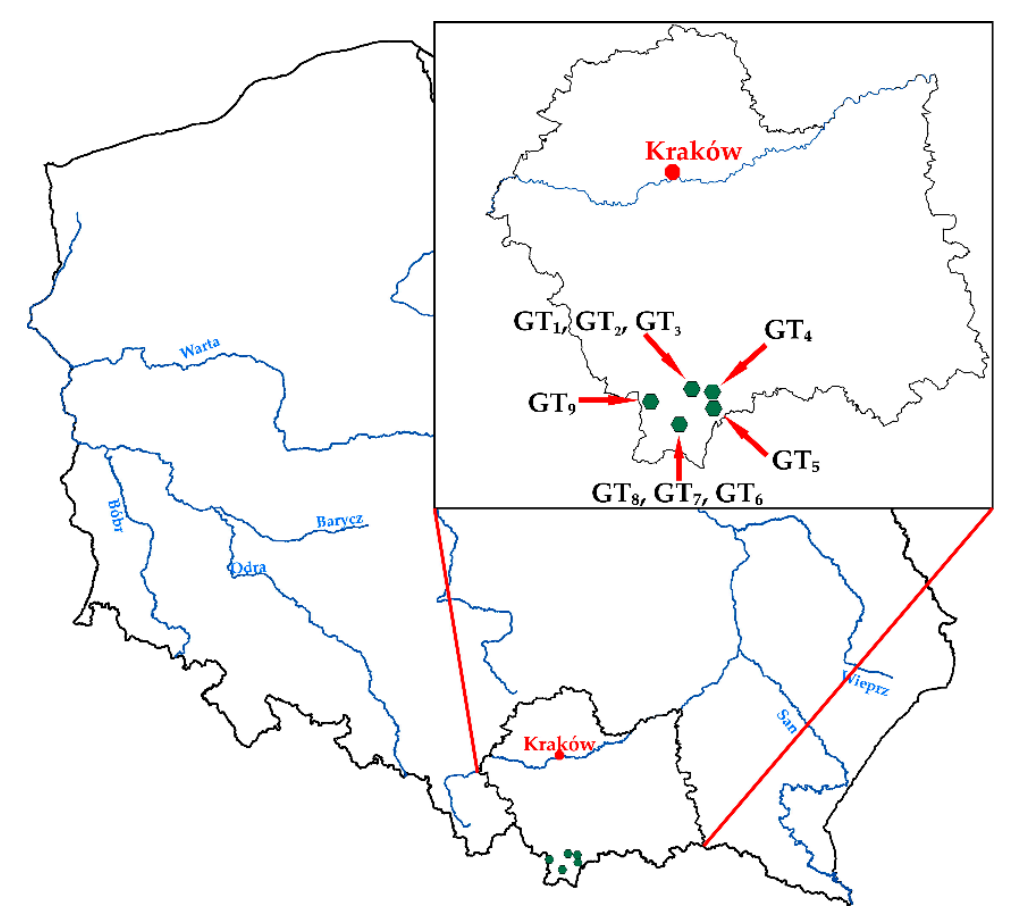

Figure 1. Map of geothermal water well locations.

This geothermal water is mainly used for heating purposes, as well as in recreational centers, bathing areas and balneological therapies. On a small scale, geothermal water in Poland is used in fish farming (Atlantic salmon), food processing, wood drying, heating sports facilities, cosmetic production and recovery of iodine and bromine salts $[17,35]$. In Podhale, after recovery of heat and cooling in the heat exchanger, water is reinjected into the geological structure with the use of two receptive holes or discharged into surface water.

The Podhale geothermal reservoir comprises two major units of geological structure. The first one is composed of the Paleogene formation (Upper Eocene-Oligocene), which is the cover of the geothermal aquifer, and the Eocene carbonate series (Middle-Upper Eocene), which is the aquifer roof. The second unit is considered to be the water-bearing rocks of the Mesozoic formations (Lower Triassic-Jurassic-Middle Cretaceous). The thickness of the Paleogene series reaches $2.5-3.2 \mathrm{~km}$, whereas that of the Mesozoic series exceeds $2.5 \mathrm{~km}$. The depths of the boreholes actively exploiting geothermal water are in the range of 1 to $3.5 \mathrm{~km}[20,36-38]$.

In this study, geothermal water samples from nine working wells (named $\mathrm{GW}_{1}-\mathrm{GW}_{9}$ ) were analyzed.

The archival data were collected from long-term water monitoring conducted between 2010 and 2019 ( $\mathrm{N}=236$ samples). The gathered data included values and concentrations of selected parameters, both physical ( $\mathrm{pH}$, electrical conductivity (EC) and temperature (T)) and chemical (major ions and specific components-where applicable). The unstable parameter measurements and chemical composition analyses were performed by different laboratories during the investigated period. The number of individual analyses for each intake is different due to the varying frequency of water monitoring research. These data were used to estimate variability in the physicochemical composition of analyzed water.

To avoid the influence of changes in sampling process and analysis methods on the risk assessment, the collection of samples from the nine working wells $\left(\mathrm{GW}_{1}-\mathrm{GW}_{9}\right)$ for the risk assessment and modeling experiments was carried out on the same day (in October 2019), by one person, according to the requirements precisely described in ISO 5667-11:2009 [39]. The geothermal water wells were rinsed ca. $15 \mathrm{~min}$ before sampling and unstable parameter measurements to ensure the stability of the chemical composition of the water and avoid the contamination of water samples with substances that could be 
present in an internal installation system. Stability was considered to be achieved if the consecutive measurements did not differ by $0.2{ }^{\circ} \mathrm{C}$ for temperature, 0.1 for $\mathrm{pH}$ and $5 \%$ for $\mathrm{EC}[7,40,41]$.

Furthermore, the laboratory and field QA/QC programs were implemented to ensure that samples were not contaminated during collection and transport. The QA/QC programs involved the collection of laboratory and field blank samples, duplicate samples and samples spiked with a known amount of total chromium. Application of the quality assurance and quality control programs allowed for calculation of statistical parameters to check if the sampling process and chemical analyses were done properly. All of the samples were collected in high-density polyethylene bottles and immediately transported to the laboratory.

During fieldwork, the following normal geothermal water samples and control samples were collected:

1. Nine normal unfiltered water samples were used for the determination of bicarbonates and chlorides by titration methods.

2. Nine normal water samples were filtered with a membrane filter of $0.45 \mu \mathrm{m}$ pore diameter and acidified with concentrated nitric acid ( $1 \mathrm{~mL} \mathrm{HNO}_{3}$ per $100 \mathrm{~mL}$ of water sample) to allow for the control of the chemical analyses by ionic charge balance; these samples were used to analyze the concentrations of major ions, total chromium and other trace elements, considering detailed characteristics.

3. Two duplicate control samples were collected in the same way as the normal ones from randomly selected intakes; these samples were used to check the repeatability, expressed as relative percentage difference (RPD) between chemical analyses.

4. One blank (field) control sample was used to verify the influence of the transport process on the contamination of water samples and to compare with the laboratory blank.

5. Nine normal samples and one blank sample were spiked with a known amount $\left(10 \mu \mathrm{g} \cdot \mathrm{L}^{-1}\right)$ of total chromium to check the accuracy (recovery) of the chemical analyses.

\subsection{Reagents, Solutions and Reference Materials}

Deionized water $(18.2 \mathrm{M} \Omega \cdot \mathrm{cm})$ for blank samples was obtained using the Milli-Q system (Millipore, Bedford, MA, USA,). Working solutions were prepared by dilution with acidified (Nitric Acid, 69.0-70.0\%, BAKER INSTRA-ANALYZED Reagent) deionized water as necessary. The standard solutions (ICP multielement standard IV and VI Certipur and V TraceCERT, Merck) with certified values were used for the spectrometer calibration. Certified reference material (TMDA 64.3 ECCC) and an environmental water sample (treated as an additional control sample) with a known matrix were used for quality control during instrumentation. For titration methods, the duplicate samples and certified reference material were analyzed (ION 96.4 ECCC). While the samples underwent the measurements of the physical parameters, the quality program included calibration and control of $\mathrm{pH}$ and EC probes with appropriate buffers (Hamilton, VWR), and temperature measurements were conducted with a calibrated thermometer with a specific calibration certificate.

\subsection{Instrumentation}

Field measurements of $\mathrm{pH}$ value, oxidation-reduction potential $\left(\mathrm{E}_{\mathrm{H}}\right)$ and electrical conductivity (EC) were conducted with the use of a WTW Multimeter (ProfiLine pH/Cond 3320). The temperature was measured with a calibrated liquid thermometer whose scale covered the temperature range of geothermal water. The measurements were conducted according to the ISO standards $[39,42,43]$.

The samples were analyzed for total chromium concentration using an Optima 7300 DV inductively coupled plasma optical emission spectrometer (ICP-OES) from PerkinElmer [44] in the Hydrogeochemical Laboratory of the Department of Hydrogeology and Engineering Geology at AGH University of Science and Technology. 
Moreover, during instrumental analysis performed in the laboratory the inductively coupled plasma optical emission spectrometry (ICP-OES), inductively coupled plasma mass spectrometry (ICP-MS; Elan 6100, PerkinElmer) and titration methods were used for determination of particular elements used for control of ionic charge balance of each chemical analysis, the denomination of hydrochemical type of the geothermal water and for speciation modeling.

The ICP-OES method was used not only for the chromium analyses but also for the determination of $\mathrm{Ca}, \mathrm{Fe}, \mathrm{K}, \mathrm{Li}, \mathrm{Mg}, \mathrm{Mn}, \mathrm{Na}, \mathrm{S}$ (recalculated on $\mathrm{SO}_{4}{ }^{2-}$ ), $\mathrm{Si}$, $\mathrm{Sr}$ and $\mathrm{Zn}$; ICP-MS was used for determination of trace elements ( $\mathrm{Ag}, \mathrm{Al}, \mathrm{As}, \mathrm{B}, \mathrm{Ba}, \mathrm{Be}, \mathrm{Br}, \mathrm{Cd}, \mathrm{Co}, \mathrm{Cu}, \mathrm{Hg}, \mathrm{I}, \mathrm{Mo}, \mathrm{Ni}, \mathrm{P}$ (recalculated on $\mathrm{PO}_{4}{ }^{3-}$ ), $\mathrm{Pb}, \mathrm{Sb}$, $\mathrm{Se}, \mathrm{Ti}, \mathrm{Tl}, \mathrm{V}, \mathrm{W}$ and $\mathrm{Zr}$ ); and titration methods were used determination of bicarbonates and chlorides, according to the standards given in [44-47]. The characteristic parameters (like precision, accuracy and uncertainty) for the determination of selected compounds with the use of each method are presented in Table S1. Estimations include the sampling process.

The laboratory has implemented an internal quality control system and participates regularly in proficiency tests and interlaboratory comparisons with satisfactory results ( $Z$ score absolute value lower than 2).

The precision of the analytical methods used, expressed as a relative standard deviation (\%RSD) was determined by the laboratory during a standard process of method validation and was lower than $20 \%$. The precision of chromium determination by the ICP-OES method that was obtained by the laboratory was $2.09 \%$. The recovery values for all parameters were in range of $94-105 \%$; the recovery value for $\mathrm{Cr}$ was established at $100.3 \%$. Both parameters met the requirements contained in worldwide guidelines [48]. Expanded measurement uncertainty took into account all of the characteristic method parameters, and its values for all chemical compounds were in the range of $10-19 \%$; for chromium, it was equal to $13.38 \%$.

\subsection{Speciation Modeling}

Concentrations of chromium speciation in the analyzed geothermal water samples were calculated using a program created by the United States Geological Survey (USGS)-PHREEQC. Hydrogeochemical modeling is based on initial conditions of the solution entered into the program, i.e., $\mathrm{pH}$, temperature, oxidation-reduction potential and concentrations of individual elements. The calculations were conducted with the use of the MINTEQ database because only this one allows for the determination of chromium speciation [49].

Redox potential was indirectly used in modeling of chromium speciation in the particular geothermal water collected. For the needs of speciation modeling, $\mathrm{E}_{\mathrm{H}}$ was presented as a theoretical activity of electrons in a solution (pe) $[50,51]$. Then, the temperature of each geothermal water sample was applied, and other parameters were applied as needed.

\subsection{Risk Assessment}

The geothermal water analyzed here is used for recreational purposes, so the main hazard due to the presence of chromium this water results from the possibility of its direct contact with the skin during bathing in thermal pools. For this reason, the potential health risk associated with chromium occurrence was assessed. The calculations were conducted separately for adults, teenagers and children [52]. The hazard quotient $(\mathrm{HQ})$ and daily intake through dermal absorption $\left(\mathrm{EDI}_{\text {derm }}\right)$ were estimated [53]. The risk assessment was conducted in two ways. The first scenario included the deterministic approach where the results obtained from chemical analyses were directly used in calculations. In the second approach, the measurement uncertainty estimated during laboratory investigations was included in the decision process. Both calculations were based on results whose reliability was verified during the examination of the instrumental methods.

Extensive use of this geothermal water can also be hazardous for the environment, with the main source of this hazard being water discharge to surface watercourses after heat is recovered heat from it. Therefore, the environmental risk was also assessed using a $5 \times 5$ risk matrix $[54,55]$. 


\section{Results and Discussion}

The authors have gathered archival data regarding the chemical composition of geothermal water in studied wells. The archival experiments were usually conducted for the major ions and/or the specific components that can give a medicinal character to the water, especially when it is used in balneology and thermal spas. The mean values of the basic field parameters ( $\mathrm{pH}, \mathrm{EC}$ and temperature) and concentrations of major ions determining the hydrochemical type are presented in Table S2.

The analysis confirmed the studies conducted by many scientists which revealed that the chemical composition of geothermal water of the Podhale Trough is stable over time [33,37,56-60]. The results of our study were compared to archival data and are in the range of natural changes in the chemical composition of investigated geothermal water (Figure S1). Therefore the further analyses are based on the results of the latest sampling series.

Results of analyses of selected physicochemical parameters (such as $\mathrm{pH}$, redox potential $\left(\mathrm{E}_{\mathrm{H}}\right)$, electrical conductivity (EC), temperature (T), total dissolved solids (TDS), fluoride ion concentration, metasilicic acid content and hence hydrochemical type) in collected samples are presented in Table 1. The results were used in geochemical modeling.

Table 1. Physicochemical characteristics of the analyzed geothermal water-results of the latest sampling series.

\begin{tabular}{|c|c|c|c|c|c|c|c|c|}
\hline $\begin{array}{l}\text { Geothermal } \\
\text { Water Well }\end{array}$ & $\mathrm{pH}$ & $\begin{array}{c}\mathrm{E}_{\mathrm{H}} \\
(\mathrm{mV})\end{array}$ & $\begin{array}{c}\mathrm{EC} \\
(\mathrm{mS} / \mathrm{cm})\end{array}$ & $\begin{array}{c}\mathrm{T} \\
\left({ }^{\circ} \mathrm{C}\right)\end{array}$ & $\begin{array}{c}\text { TDS } \\
\left(\mathrm{mg} \cdot \mathrm{L}^{-1}\right)\end{array}$ & $\begin{array}{c}\mathrm{F}^{-} \\
\left(\mathrm{mg} \cdot \mathrm{L}^{-1}\right)\end{array}$ & $\begin{array}{c}\mathrm{H}_{2} \mathrm{SiO}_{3} \\
\left(\mathrm{mg} \cdot \mathrm{L}^{-1}\right)\end{array}$ & Hydrochemical Type \\
\hline $\mathrm{GW}_{1}$ & 6.64 & -5.9 & 3.41 & 84.9 & 2192.9 & 2.62 & 69.25 & $\mathrm{SO}_{4}-\mathrm{Cl}-\mathrm{Na}-\mathrm{Ca}, \mathrm{F}$ \\
\hline $\mathrm{GW}_{2}$ & 6.67 & 103.8 & 3.38 & 83.8 & 2215.8 & 2.62 & 69.00 & $\mathrm{SO}_{4}-\mathrm{Cl}-\mathrm{Na}-\mathrm{Ca}, \mathrm{F}$ \\
\hline $\mathrm{GW}_{3}$ & 6.63 & -118.1 & 3.42 & 67.4 & 2245.6 & 2.66 & 70.79 & $\mathrm{SO}_{4}-\mathrm{Cl}-\mathrm{Na}-\mathrm{Ca}, \mathrm{H}_{2} \mathrm{SiO}_{3}, \mathrm{~F}$ \\
\hline $\mathrm{GW}_{4}$ & 6.91 & -117.6 & 2.53 & 74.5 & 1648.8 & 2.47 & 63.73 & $\mathrm{SO}_{4}-\mathrm{Cl}-\mathrm{Na}-\mathrm{Ca}, \mathrm{F}$ \\
\hline $\mathrm{GW}_{5}$ & 6.91 & -182.5 & 2.04 & 60.5 & 1446.5 & 2.64 & 48.79 & $\mathrm{SO}_{4}-\mathrm{Na}-\mathrm{Ca}, \mathrm{F}$ \\
\hline $\mathrm{GW}_{6}$ & 7.56 & -135.9 & 0.42 & 34.7 & 253.5 & 0.346 & 19.89 & $\mathrm{HCO}_{3}-\mathrm{Ca}-\mathrm{Mg}$ \\
\hline $\mathrm{GW}_{7}$ & 7.55 & -72.2 & 0.40 & 23.3 & 222.0 & 0.223 & 7.98 & $\mathrm{HCO}_{3}-\mathrm{Ca}-\mathrm{Mg}$ \\
\hline $\mathrm{GW}_{8}$ & 7.53 & -129.7 & 0.330 & 25.4 & 186.6 & 0.178 & 5.73 & $\mathrm{HCO}_{3}-\mathrm{Ca}-\mathrm{Mg}$ \\
\hline $\mathrm{GW}_{9}$ & 6.65 & -153.7 & 1.39 & 76.9 & 1077.8 & 1.48 & 64.66 & $\mathrm{SO}_{4}-\mathrm{Ca}$ \\
\hline
\end{tabular}

In light of the Polish regulations described in Geological and Mining Law [61], groundwater with a temperature above $20^{\circ} \mathrm{C}$ can be treated not only as geothermal water but also potentially as curative water. These laws also mention criteria regarding the minimum concentrations of the chemical parameters, i.e., fluoride $\left(2 \mathrm{mg} \cdot \mathrm{L}^{-1}\right)$ and silica expressed as a concentration of the metasilicic acid $\left(70 \mathrm{mg} \cdot \mathrm{L}^{-1}\right)$, above which the water can have medicinal properties. According to the data collected during fieldwork, it can be seen that the water from all wells can be treated as geothermal. It could be used in balneotherapy due to the occurrence of specific components such as fluorides and metasilicic acid at the levels exceeding the threshold values recommended $\left(\mathrm{GW}_{1}-\mathrm{GW}_{5}\right)$.

According to the purpose of the presented article and the fact that authors have focused on chromium in investigated geothermal water, the shortened verification of the ICP-OES method was applied. The verification included calculation of the laboratory limit of quantification, estimation of the variability during analysis and, as the last step, calculation of the expanded measurement uncertainty. A low chromium concentration was expected based on previously observed values during long-term water monitoring in the $\mathrm{GW}_{1}$ well. The measured total chromium concentrations were in the range of $1-3 \mu \mathrm{g} \cdot \mathrm{L}^{-1}$ (Figure 2).

The laboratory limit of quantification (LOQ) of chromium was calculated based on the results of repeated measurements of consecutive laboratory blank samples in relation to the formula presented by Fleming et al. [62] on the level of $1 \mu \mathrm{g} \cdot \mathrm{L}^{-1}$.

Obtained relative percentage differences (\%RPD) were calculated based on the duplicate control samples and reached 5.7 and $12.2 \%$ for current studies. The obtained RPD values are lower than $20 \%$, which is a maximum permissible value in environmental research $[48,63]$. 


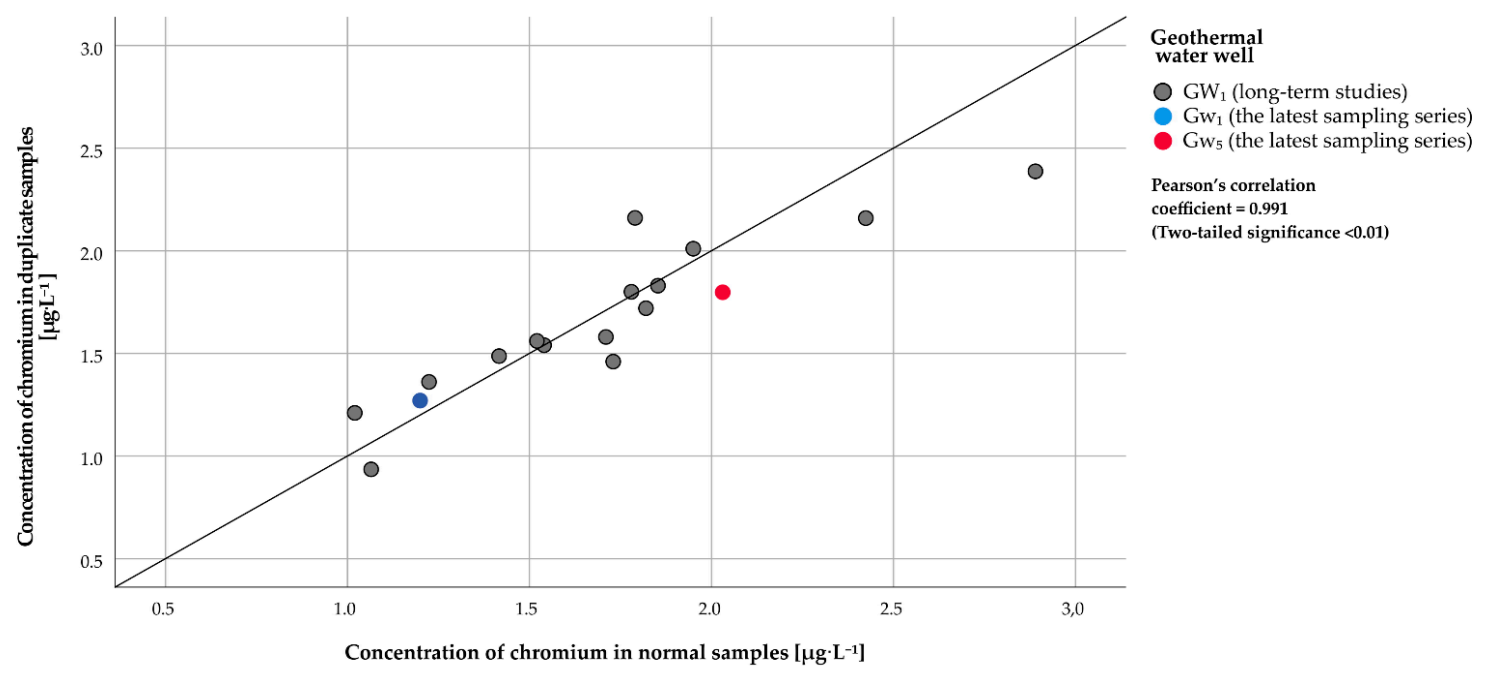

Figure 2. Concentration of chromium in normal and duplicate samples during long-term monitoring.

Recovery was assessed by the analysis of the spiked samples where the added known concentration of chromium standard solution was $10 \mu \mathrm{g} \cdot \mathrm{L}^{-1}$. The results of recovery were obtained by comparison of spiked and unspiked samples for all geothermal water intakes. Calculated values of recovery were in the range $93-114 \%$ with an average of $100.9 \%$ and met requirements of international standards [48].

Calculated relative standard uncertainty for chromium determination at the level of $1 \mu \mathrm{g} \cdot \mathrm{L}^{-1}$ in the current study is $18.7 \%$, and relative expanded uncertainty (U) is $37.4 \%$ (expansion coefficient $\mathrm{k}=2$, confidence level of $95 \%$ ). The $\mathrm{Cr}$ concentrations determined during the last sampling campaign together with estimated measurement uncertainty are presented in Table 2.

Table 2. Results of Cr determination and measurement uncertainty (U).

\begin{tabular}{cc}
\hline $\begin{array}{c}\text { Geothermal } \\
\text { Water Well }\end{array}$ & $\begin{array}{c}\mathbf{C r}_{\text {tot }} \pm \mathbf{U} \\
\left(\boldsymbol{\mu g} \cdot \mathbf{L}^{-\mathbf{1}}\right)\end{array}$ \\
\hline $\mathrm{GW}_{1}$ & $1.20 \pm 0.45$ \\
$\mathrm{GW}_{2}$ & $1.06 \pm 0.40$ \\
$\mathrm{GW}_{3}$ & $1.10 \pm 0.41$ \\
$\mathrm{GW}_{4}$ & $1.40 \pm 0.52$ \\
$\mathrm{GW}_{5}$ & $2.03 \pm 0.76$ \\
$\mathrm{GW}_{6}$ & $1.19 \pm 0.45$ \\
$\mathrm{GW}_{7}$ & $1.89 \pm 0.71$ \\
$\mathrm{GW}_{8}$ & $1.05 \pm 0.39$ \\
$\mathrm{GW}$ & $2.18 \pm 0.82$ \\
\hline
\end{tabular}

Most of geothermal water exhibits reducing properties [2,64,65]. In light of a previously conducted study, all of the analyzed geothermal water samples represent reducing conditions, with $\mathrm{E}_{\mathrm{H}}$ varying from -5.9 to $-182.5 \mathrm{mV}$ and temperature ranging from 25.4 to $76.9^{\circ} \mathrm{C}$.

\subsection{Speciation Modeling Results}

The results of chromium speciation modeling are presented in Table 3. They show that the predominant form of chromium occurrence in the geothermal water basin of Podhale is probably $\mathrm{Cr}$ (III). Almost $100 \%$ of all chromium concentration in geothermal water is represented by the more stable form of chromium - trivalent-occurring in geothermal water due to reducing conditions of the aquatic environment tested $[2,64,65]$. 
Table 3. Results of chromium speciation modeling.

\begin{tabular}{cccc}
\hline $\begin{array}{c}\text { Geothermal } \\
\text { Water Well }\end{array}$ & $\begin{array}{c}\mathbf{C r}_{\text {tot }} \\
\left(\boldsymbol{\mu g} \cdot \mathbf{L}^{-\mathbf{1}}\right)\end{array}$ & $\begin{array}{c}\mathrm{Cr}(\mathrm{III}) \\
\left(\boldsymbol{\mu g} \cdot \mathbf{L}^{-\mathbf{1}}\right)\end{array}$ & $\begin{array}{c}\mathbf{C r}(\mathrm{VI}) \\
\left(\boldsymbol{\mu} \mathbf{g} \cdot \mathbf{L}^{-\mathbf{1}}\right)\end{array}$ \\
\hline $\mathrm{GW}_{1}$ & 1.20 & 1.20 & $1.30 \times 10^{-19}$ \\
$\mathrm{GW}_{2}$ & 1.06 & 1.06 & $7.56 \times 10^{-22}$ \\
$\mathrm{GW}_{3}$ & 1.10 & 1.10 & $5.44 \times 10^{-24}$ \\
$\mathrm{GW}_{4}$ & 1.40 & 1.40 & $3.91 \times 10^{-22}$ \\
$\mathrm{GW}_{5}$ & 2.03 & 2.03 & $2.62 \times 10^{-29}$ \\
$\mathrm{GW}_{6}$ & 1.19 & 1.19 & $1.72 \times 10^{-27}$ \\
$\mathrm{GW}_{7}$ & 1.89 & 1.89 & $3.66 \times 10^{-27}$ \\
$\mathrm{GW}_{8}$ & 1.05 & 1.05 & $4.88 \times 10^{-31}$ \\
$\mathrm{GW}_{9}$ & 2.18 & 2.18 & $3.51 \times 10^{-23}$ \\
\hline
\end{tabular}

The modeled concentration of the hexavalent form is negligible $\left(<10^{-19} \mu \mathrm{g} \cdot \mathrm{L}^{-1}\right)$ and does not influence the total concentration of $\mathrm{Cr} ; \mathrm{Cr}_{\text {tot }} \cong \mathrm{Cr}(\mathrm{III})$ (Table 3). The concentrations of total chromium and hence $\mathrm{Cr}(\mathrm{III})$ in particular geothermal water wells vary from 1.0 to $2.2 \mu \mathrm{g} \cdot \mathrm{L}^{-1}$. The concentrations of $\mathrm{Cr}_{\text {tot }}$ were always below the threshold values of $50 \mu \mathrm{g} \cdot \mathrm{L}^{-1}$ recommended for drinking water under international and Polish law [14-16]. Furthermore, the results obtained, enlarged by measurement uncertainty estimation, do not influence the use of this water in balneotherapeutic drinking purposes, inhalation and external use, where the maximum $\mathrm{Cr}$ concentration was established at the level $10 \mu \mathrm{g} \cdot \mathrm{L}^{-1}$ [31]. Many tests were done regarding the reuse of geothermal water from the Podhale Trough. Research studies were conducted which proved that after reverse osmosis processes water (permeate) could be successfully used as drinking water after secondary enrichment in minerals. It is also possible to recover balneological resources from the retentate, where the concentrations of substances are increased [21,66,67].

Taking into account the results obtained in this study, it can be seen that the concentrations of total chromium in geothermal water in the Podhale Trough are in the range of the natural hydrogeochemical background for this element $\left(0.1-10 \mu \mathrm{g} \cdot \mathrm{L}^{-1}\right)$. In clean groundwater, its concentrations do not exceed $20 \mu \mathrm{g} \cdot \mathrm{L}^{-1}$ [7]. In studies conducted considering the natural geothermal fluids in the world, the concentration of $\mathrm{Cr}_{\text {tot }}$ was found to be in the range of $<0.01-660 \mu \mathrm{g} \cdot \mathrm{L}^{-1}$ in Iceland and reached $330 \mu \mathrm{g} \cdot \mathrm{L}^{-1}$ in Turkey $[2,68]$. The concentration of total chromium is strongly dependent on the $\mathrm{pH}$ of the geothermal water and presence of ions such as $\mathrm{SO}_{4}{ }^{2-}, \mathrm{HCO}_{3}{ }^{-}, \mathrm{Cl}^{-}, \mathrm{Ca}^{2+}, \mathrm{Mg}^{2+}$ and $\mathrm{Na}^{+}[2,68]$. In natural geothermal water, $\mathrm{Cr}$ (III) exists mostly in the form of metal hydroxy speciation, where the hydroxides play the role of ligands [69]. In natural water, it is desirable to have $\mathrm{Cr}(\mathrm{III})$ as the prevailing speciation (as opposed to $\mathrm{Cr}(\mathrm{VI})$ ) due to its nontoxic properties. The presence of hexavalent chromium in nature is rare [70]. Its environmental presence is related to industrial activities (e.g., tanneries, chromium ore processing plants, slag-soil systems or deposition of steel production waste on landfills) [7,71-74]. In particular, $\mathrm{Cr}(\mathrm{VI})$ in natural water may occur in surface water near which chromite-bearing formations are observed [5] The differences in chromium speciation ratio $(\mathrm{Cr}(\mathrm{III}) / \mathrm{Cr}(\mathrm{VI}))$ may be a result of seasonal changes [75].

\subsection{Analysis of the Risk of Exposure to Chromium}

The geothermal water analyzed here is used for recreational purposes. The main hazard due to the presence of chromium in this water results from the possibility of its direct contact with the skin during bathing in thermal pools. For this reason, the potential health risk associated with chromium occurrence was assessed. The chromium concentration in the risk model was set as $2 \mu \mathrm{g} \cdot \mathrm{L}^{-1}$ (deterministic approach), as this was the highest value that was found in the geothermal water analyzed here. Calculations were conducted separately for adults, teenagers and children (Fallahzadeh et al. 
2018). The hazard quotient $\left(\mathrm{HQ}_{\mathrm{derm}}\right)$ and daily intake through dermal absorption $\left(\mathrm{EDI}_{\mathrm{derm}}\right)$ were calculated as follows (USEPA 2016):

$$
\begin{gathered}
\mathrm{HQ}_{\text {derm }}=\frac{\mathrm{EDI}}{\mathrm{RfD}} \\
\mathrm{EDI}_{\text {derm }}=\frac{\mathrm{C}_{\mathrm{W}} \cdot \mathrm{SA} \cdot \mathrm{K}_{\mathrm{p}} \cdot \mathrm{F} \cdot \mathrm{ETs} \cdot \mathrm{EF} \cdot \mathrm{ED} \cdot 10^{-3}}{\mathrm{BW} \cdot \mathrm{AT}}
\end{gathered}
$$

where RfD is a reference dose of chromium in a specific exposure pathway $\left(\mathrm{mg} \cdot \mathrm{kg}^{-1} \cdot \mathrm{day}^{-1}\right)$, set as $1.5 \times 10^{-5} \mathrm{mg} \cdot \mathrm{kg}^{-1} \cdot \mathrm{day}^{-1}$ after Smith (1994) and Fallahzadeh et al. [52]; $\mathrm{C}_{\mathrm{W}}$ is a concentration of chromium in geothermal water; SA is surface area and was set as $18,182 \mathrm{~cm}^{2}$ for adults, $14,321 \mathrm{~cm}^{2}$ for teens and $7422 \mathrm{~cm}^{2}$ for children (after Wu et al. [76]); $\mathrm{K}_{\mathrm{p}}$ is a dermal permeability constant (set as $10^{-3} \mathrm{~cm} \cdot \mathrm{h}^{-1}$ after Williams et al. [77]); $\mathrm{F}$ is a fraction of surface skin contact with water and was set as 0.9 (after Williams et al. [77]); ETs represents exposure time and was estimated at $0.004 \mathrm{~h} \cdot \mathrm{day}^{-1}$ ( $3 \mathrm{~h} \mathrm{a}$ month) in the swimming pool; EF is exposure frequency and was set as 12 days.year ${ }^{-1}$; ED is exposure duration, set as 50 years for adults, 15 years for teens and 6 years for children [78]; BW is body weight and was set as $79 \mathrm{~kg}$ for adults, $61.5 \mathrm{~kg}$ for teens and $23.6 \mathrm{~kg}$ for children (on-line access (04.04.2019): https://bit.ly/2TSUoHZ); and AT is averaging time and was set as 18,250 days for adults, 5475 days for teens and 2190 days for children [78].

Calculated daily intake of chromium through epidermal absorption $\mathrm{EDI}_{\text {derm }}$ is $5.45 \times 10^{-11} \mathrm{mg} \cdot \mathrm{kg}^{-1} \cdot \mathrm{day}^{-1}$ for adults, $5.51 \times 10^{-11} \mathrm{mg} \cdot \mathrm{kg}^{-1} \cdot \mathrm{day}^{-1}$ for teens and $7.44 \times 10^{-11} \mathrm{mg} \cdot \mathrm{kg}^{-1} \cdot \mathrm{day}^{-1}$ for children. The estimated $\mathrm{HQ}_{\text {derm }}$ values are lower than 1 in all age groups (Table 4). The risk of being exposed to chromium poisoning is low, which is confirmed by the $\mathrm{HQ}_{\text {derm }}$ values obtained: $3.6 \times 10^{-6}, 3.7 \times 10^{-6}$ and $5.0 \times 10^{-6}$ for adults, teens and children respectively. It can be stated that for three to five people out of one million are exposed to chromium poisoning by epidermal absorption. In general, where the $\mathrm{HQ}_{\mathrm{derm}}$ values are lower than 1 , the noncarcinogenic health effects from different trace elements in the human population are unlikely $[53,79,80]$.

Table 4. The results of health risk assessment.

\begin{tabular}{cccc}
\hline \multirow{2}{*}{ Parameter } & \multicolumn{3}{c}{ Age Group } \\
\cline { 2 - 4 } & Adults & Teenagers & Children \\
\hline & Deterministic approach \\
$\mathrm{EDI}_{\mathrm{derm}}\left(\mathrm{mg} \cdot \mathrm{kg}^{-1} \cdot \mathrm{day}^{-1}\right)$ & $5.45 \times 10^{-11}$ & $5.51 \times 10^{-11}$ & $7.44 \times 10^{-11}$ \\
$\mathrm{HQ}_{\text {derm }}$ & $3.6 \times 10^{-6}$ & $3.7 \times 10^{-6}$ & $5.0 \times 10^{-6}$ \\
Approach including measurement uncertainty & \\
$\mathrm{EDI}_{\mathrm{derm}}\left(\mathrm{mg}_{\mathrm{kg}}{ }^{-1} \cdot\right.$ day $\left.^{-1}\right)$ & $7.49 \times 10^{-11}$ & $7.57 \times 10^{-11}$ & $1.02 \times 10^{-10}$ \\
$\mathrm{HQ} \mathrm{derm}$ & $5.0 \times 10^{-6}$ & $5.0 \times 10^{-6}$ & $6.8 \times 10^{-6}$ \\
\hline
\end{tabular}

The second approach, which took into account the estimated relative expanded uncertainty, was also applied (Table 4). Here, the only parameter that changed was chromium concentration, which rose from 2 to $2.74 \mu \mathrm{g} \cdot \mathrm{L}^{-1}$ (upper limit of uncertainty interval). In consequence, $\mathrm{EDI}_{\mathrm{derm}}$ rose to $7.49 \times 10^{-11} \mathrm{mg} \cdot \mathrm{kg}^{-1} \cdot \mathrm{day}^{-1}$ in the adults, $7.57 \times 10^{-11} \mathrm{mg} \cdot \mathrm{kg}^{-1} \cdot \mathrm{day}^{-1}$ in teens and $1.02 \times 10^{-10}$ $\mathrm{mg} \cdot \mathrm{kg}^{-1} \cdot \mathrm{day}^{-1}$ in children. The $\mathrm{HQ}_{\mathrm{derm}}$ is still lower than 1 , even though the values grew to $5.0 \times 10^{-6}$, $5.0 \times 10^{-6}$ and $6.8 \times 10^{-6}$ for adults, teens and children, respectively.

For health risk assessment, not only the concentration of heavy metal but also the degree of metal intake by an organism is important in influencing the final result. HQ calculations are generally based on total concentrations of heavy metals. The correlation between adsorption of heavy metals by an organism and total concentrations of metals is neglected. The intake dose of toxic forms, i.e., $\mathrm{Cr}(\mathrm{VI})$ and especially its aqueous morphologies present in water, should be taken into account because the speciation of heavy metals, rather than their total concentrations, plays a significant role in assessing health risk [81]. In the worldwide research, a noncancerogenic hazard quotient for groundwater 
with a low epidermal adsorption effect was calculated to be on the level of $0.155 \mathrm{mg} \cdot \mathrm{kg}^{-1} \cdot \mathrm{day}^{-1}$ [82]. Furthermore, for groundwater used for irrigation purposes, $\mathrm{Cr}$ was found to pose a significant noncancer risk (1.20-2.99/1000 people) [80]. In the publication of Tseng et al. [83], a dynamic model for exploring the interrelationship between the Wu River watershed and contamination with $\mathrm{Cr}(\mathrm{VI})$ in the period 2018-2048 was prepared. It was found that the accumulation of $\mathrm{Cr}(\mathrm{VI})$ will be still increasing. The estimated health risk for Taiwanese people living in this agricultural region and using surface water for irrigation was in the range $10^{-4}-10^{-6}$ and led to gastric cancer. Wen et al. [84] report contamination of coastal water by the intrusion of saline water that caused the growth of heavy metals concentrations in groundwater. This growth did not increase the ecological risk, which was assessed as low, but it caused a high risk of cancer in the population of children and adults. The calculated risk was at an unacceptable level according to the intervals proposed by Fryer [85]. In turn, the work of Yin et al. (2019) showed that hexavalent chromium accumulates in edible tissues of fish, namely the head, ventral muscles and dorsal muscles. Fish farms operating in the vicinity of urbanized and industrial areas are at risk of the accumulation of heavy metals in fish; thus, people consuming these fish can be exposed to harmful factors. When considering drinking water delivered with a drinking water supply system (DWSS), attention should be paid to the possibility of pipe scaling and residual fraction occurrence from which heavy metals (including chromium) can be released. The health risks in relation to the leaching of chromium from pipe scales and the residual fraction were estimated as low and moderate, respectively. This is mainly due to the mineralogical origin of $\mathrm{Cr}$, which is bound by $\mathrm{Fe}-\mathrm{Mn}$ oxides in the case of the scaling phenomenon [86]. Another example of a health risk associated with chromium occurrence is that of the groundwater contaminated with this element near a chromite mine in Iran; the risk occurs due to the water being used for drinking and also through direct skin contact [52]. Other trace metals including chromium were examined within drinking water indigestion [87], but the HQ value for chromium did not indicate a potential toxic effect.

The risk of chromium presence in geothermal water is not only connected with human exposure risk. Extensive use of geothermal water can be hazardous for the environment, mainly during water discharge to surface watercourses after heat recovery. Therefore, the risk was assessed with the use of a $5 \times 5$ risk matrix [54,55]. Risk $\left(R_{e}\right)$ was calculated by multiplying probability (likelihood/frequency (L/F)) by impact (severity of consequence (SC)) for all of the following hazards:

1. Geothermal water injection into formation $(\mathrm{L} / \mathrm{F}=5, \mathrm{SC}=1)$.

2. Discharge of geothermal water to surface watercourses in the case of fish farming $(\mathrm{L} / \mathrm{F}=3, \mathrm{SC}=4)$.

3. Discharge of geothermal water to surface watercourses in the case of surface water chemical status changes $(\mathrm{L} / \mathrm{F}=3, \mathrm{SC}=2)$.

4. Oxidation of $\mathrm{Cr}(\mathrm{III})$ to toxic $\mathrm{Cr}(\mathrm{VI})$ due to changes in redox conditions ( $\mathrm{L} / \mathrm{F}=5, \mathrm{SC}=5)$.

For the first scenario, the $\mathrm{L} / \mathrm{F}$ factor was defined as 5 because the geothermal water is reinjected into the formation after heat recovery. For the second and third scenarios, the L/F was set as 3 because the water used for recreational purposes is discharged to the surface watercourses or/and the sewage system. The severity of consequence for the first assumption is the lowest due to the fact the reinjected water is only chilled; in this regard, there is no potential ecological risk. In the case of fish farming, SC was established at the level of four due to the possibility of accumulation of chromium in tissues $[88,89]$. The chemical status changes of surface water are not very possible due to the low concentration of $\mathrm{Cr}$ in geothermal water, and hence the $\mathrm{S} / \mathrm{C}$ factor equals 2 . The greatest potential impact on the environment is due to the oxidation of $\mathrm{Cr}(\mathrm{III})$ to the cancerogenic, mutagenic and genotoxic [53] hexavalent form; therefore, in this case, the L/F and SC have been given the highest values (5).

The risk levels were divided into minor (risk score below 5), moderate (risk score between 5 and 9) major (risk score between 10 and 19) and very severe (risk above 20) (Figure 3). 


\begin{tabular}{l|l|l|r|r|r|r|}
\multicolumn{7}{c}{ Impact } \\
\cline { 2 - 7 } & Very low & Low & Medium & High & Very high \\
\hline Highly probable & 5 & 10 & 15 & 20 & 25 \\
\hline Probable & 4 & 8 & 12 & 16 & 20 \\
\hline Possible & 3 & 6 & 9 & 12 & 15 \\
\hline Unlikely & 2 & 4 & 6 & 8 & 10 \\
\hline Rare & 1 & 2 & 3 & 4 & 5 \\
\hline
\end{tabular}

Figure 3. Semiquantitative $5 \times 5$ risk assessment matrix ([54,55], modified).

As the results show, the impacts of chromium occurrence in the geothermal water are different and dependent on the assumed scenario. In the case of injection into the formation and discharge to surface water (and therefore the possibility of chemical status changes), the potential risk is moderate. While considering discharge to surface water where potential fish farming can be set up, the risk is major. During changing the oxidation state of chromium from trivalent to hexavalent form, the environmental risk is very high when the concentration of $\mathrm{Cr}$ is significant.

Studies conducted in the scope of the health risk assessment of heavy metal intake by humans which are related to the different uses of groundwater are still expanding. Many examples in reference to other scientific areas can be found elsewhere [90-103]. Studies concerning probabilistic risk assessment in groundwater, i.e., undergoing bioremediation and quality assessment, have been conducted [104,105].

In summary, when it is possible or when there are suspicions that chromium can be an important environmental contaminant, or there is a possibility of $\mathrm{Cr}(\mathrm{VI})$ occurrence, the data collected from fieldwork should include identification of the valency of the chromium. It is actually estimated that the ratio of $\mathrm{Cr}(\mathrm{III})$ speciation to $\mathrm{Cr}(\mathrm{VI})$ is 1:6. The recognition of chromium speciation in environmental research is an issue of key importance due to the carcinogenic, mutagenic and genotoxic properties of the hexavalent form [53].

\section{Conclusions}

The main purpose of the research presented here was to evaluate the health and ecological risks of chromium in relation to geothermal water utilization. Chromium as a toxic element is quite poorly recognized in geothermal water sources around the world, as evidenced by the small number of publications on this topic. Its occurrence in trivalent or hexavalent form is dependent on various environmental conditions, i.e., geological setting, $\mathrm{pH}$ and $\mathrm{E}_{\mathrm{H}}$, and the presence of $\mathrm{Fe}, \mathrm{Al}$ and $\mathrm{Mn}$ hydroxides. Knowledge about chromium occurrence in water that can be used for drinking purposes is important for choosing the proper geothermal water treatment.

In this work, the recognition of chromium occurrence in the geothermal water from nine wells located in the Podhale Trough in Poland was presented. During field and laboratory work, the QA/QC program was implemented. The limit of quantification for chromium calculated with the ICP-OES method was $1 \mu \mathrm{g} \cdot \mathrm{L}^{-1}$, and the accuracy ranged from $93-114 \%$. The estimated relative expanded uncertainty was $37.4 \%$. Along with the uncertainty declared by the laboratory $(13.38 \%)$, it has to be mentioned that the LOQ was lowered from 2.5 to $1 \mu \mathrm{g} \cdot \mathrm{L}^{-1}$ in this study. Growth in total uncertainty is a natural factor caused by deterioration in precision and accuracy.

The results showed that the total concentration of this element in analyzed samples varied from 1.0 to $2.2 \mu \mathrm{g} \cdot \mathrm{L}^{-1}$. The dominant form of chromium occurrence is $\mathrm{Cr}(\mathrm{III})$, which is associated with reducing conditions of the aquatic system. The geothermal water can be reused as a potential source 
of drinking water, whereas the trivalent chromium can oxidize to more toxic hexavalent speciation; therefore, it is important to control the concentrations of chromium speciation in light of geothermal water being used for purposes other than heating.

Our research also introduces a novelty in the form of risk assessment for geothermal water, which is nowadays mainly used in balneotherapy. The risk assessment was conducted by using two methods: the risk model, which was used to evaluate the human exposure to chromium compounds during bathing in thermal pools, and the semiquantitative risk matrix, which was used to consider overuse and actual handling of the geothermal water of the Podhale Trough.

This research revealed that the risk of being exposed to chromium poisoning in Podhale thermal pools is low, which is confirmed by low hazard quotient $\left(\mathrm{HQ}_{\mathrm{derm}}\right)$ values. The presence of $\mathrm{Cr}$ in studied water and its impact on the environment is dependent on the assumed scenario. When considering geothermal water injection into the formation, the calculated risk $\left(R_{e}\right)$ is moderate; however, the calculated risk is moderate when the geothermal water is discharged to surface watercourses and major when the discharge occurs near fish farms. Changing the oxidation state of $\mathrm{Cr}(\mathrm{III})$ to $\mathrm{Cr}(\mathrm{VI})$ presents a very severe environmental risk if the concentration of $\mathrm{Cr}$ is significant.

Supplementary Materials: The following are available online at http://www.mdpi.com/1996-1073/13/14/3531/s1.

Author Contributions: Conceptualization, P.R. and K.W.; Methodology, P.R., K.W. and E.K.; Formal analysis, P.R., K.W. and E.K.; Data curation, P.R., K.W. and E.K.; Writing-original draft preparation, P.R., K.W.; Writing-review and editing, P.R., K.W. and E.K.; Visualization, P.R.; Supervision, E.K. All authors have read and agreed to the published version of the manuscript.

Funding: The research was funded under the AGH-UST statutory research grant No. 16.16.140.315/10.

Conflicts of Interest: The authors declare no conflict of interest.

\section{References}

1. Nriagu, J.O.; Nieboer, E. (Eds.) Chromium in the Natural and Human Environments; John Wiley \& Sons: New York, NY, USA, 1988; Volume 20.

2. Stefánsson, A.; Gunnarsson, I.; Kaasalainen, H.; Arnórsson, S. Chromium geochemistry and speciation in natural waters, Iceland. Appl. Geochem. 2015, 62, 200-206. [CrossRef]

3. Kraemer, D.; Frei, R.; Viehmann, S.; Bau, M. Mobilization and isotope fractionation of chromium during water-rock interaction in presence of siderophores. Appl. Geochem. 2019, 102, 44-54. [CrossRef]

4. Şahan, S.; Saçmacı, Ș.; Kartal, Ş.; Saçmacı, M.; Şahin, U.; Ülgen, A. Development of a new on-line system for the sequential speciation and determination of chromium species in various samples using a combination of chelating and ion exchange resins. Talanta 2014, 120, 391-397. [CrossRef] [PubMed]

5. Saputro, S.; Yoshimura, K.; Matsuoka, S.; Takehara, K.; Aizawa, J.; Tennichi, Y. Speciation of dissolved chromium and the mechanisms controlling its concentration in natural water. Chem. Geol. 2014, 364, 33-41. [CrossRef]

6. Vignati, D.A.L.; Ferrari, B.J.; Roulier, J.L.; Coquery, M.; Szalinska, E.; Bobrowski, A.; Czaplicka, A.; Kownacki, A.; Dominik, J. Chromium bioavailability in aquatic systems impacted by tannery wastewaters. Part 1: Understanding chromium accumulation by indigenous chironomids. Sci. Total Environ. 2019, 653, 401-408. [CrossRef]

7. Witczak, S.; Kania, J.; Kmiecik, E. Guidebook on Selected Physical and Chemical Indicators of Groundwater Contamination and Methods of Their Determination, 1st ed.; Inspekcja Ochrony Środowiska, Biblioteka Monitoringu Środowiska: Warszawa, Poland, 2013. (In Polish)

8. Eisen-Cuadra, A.; Christian, A.D.; Dorval, E.; Broadaway, B.; Herron, J.; Hannigan, R.E. Metal geochemistry of a Brackish lake: Étang Saumâtre, Haiti. In Medical Geochemistry, 1st ed.; Censi, P., Darrah, T., Erel, Y., Eds.; Springer: Dordrecht, The Netherlands, 2013; pp. 149-166.

9. Pędziwiatr, A.; Kierczak, J.; Waroszewski, J. Nickel, chromium and cobalt-bearing minerals in various ultrabasic rocks of lower Silesia (southwestern Poland). In Proceedings of the 4th Central European Mineralogical Conference, Skalský Dvưr, Czech Republic, 23-26 April 2014.

10. Selinus, O.; Alloway, B.; Centeno, J.A.; Finkelman, R.B.; Fuge, R.; Lindh, U.; Smedley, P. (Eds.) Essentials of Medical Geology; Revised Edition; Springer: New York, NY, USA, 2013. 
11. Cohen, M.D.; Kargacin, B.; Klein, C.B.; Costa, M. Mechanisms of chromium carcinogenicity and toxicity. Crit. Rev. Toxicol. 1993, 23, 255-281. [CrossRef]

12. Mertz, W.; Toepfer, E.W.; Roginski, E.E.; Polansky, M.M. Present knowledge of the role of chromium. Fed. Proc. 1974, 33, 2275-2280.

13. Pradhan, D.; Sukla, L.B.; Sawyer, M.; Rahman, P.K. Recent bioreduction of hexavalent chromium in wastewater treatment: A review. J. Ind. Eng. Chem. 2017, 55, 1-20. [CrossRef]

14. European Comission. Council Directive 98/83/EC of 3 November 1998 On the Quality of Water Intended for Human Consumption; European Comission: Brussels, Belgium, 1998.

15. WHO. Guidelines for Drinking-Water Quality, 4th ed.; 1. Potable Water-Standards. 2. Water-Standards. 3. Water Quality—Standards. 4. Guidelines; World Health Organization: Geneva, Switzerland, 2011; p. 541.

16. RMH. Regulation of the Minister of the Health of Poland, of 11 December on the Scope of Water Intended for Human Consumption. J. Laws 2017.

17. Kępińska, B. Przegląd stanu wykorzystania energii geotermalnej w Polsce w latach 2016-2018. Technika Poszukiwań Geologicznych 2018, 57, 11-26. (In Polish)

18. RMH. Regulation of the Minister of Health of Poland, of 9 November 2015 on the Requirements that Should Be Fulfill by the Water at the Swimming Pools. J. Laws 2015.

19. Mika, A.; Kmiecik, E.; Krawiec, A.; Wattor, K.; Zamfir, M.; Chochorek, A. Legionella pneumophila in Thermal Spa-Methodological Aspects of Sampling and Analysis. Geomicrobiol. J. 2019, 36, 460-467. [CrossRef]

20. Bujakowski, W.; Tomaszewska, B.; Miecznik, M. The Podhale geothermal reservoir simulation for long-term sustainable production. Renew. Energ. 2016, 99, 420-430. [CrossRef]

21. Kmiecik, E.; Tomaszewska, B.; Wator, K.; Bodzek, M. Selected problems with boron determination in water treatment processes. Part I: Comparison of the reference methods for ICP-MS and ICP-OES determinations. Environ. Sci. Pollut. Res. 2016, 23, 11658-11667. [CrossRef] [PubMed]

22. Tomaszewska, B.; Kmiecik, E.; Wator, K. Evaluating the stability of iodine in bottled mineral waters. J. Geochem. Explor. 2016, 168, 20-25. [CrossRef]

23. Tomaszewska, B.; Rajca, M.; Kmiecik, E.; Bodzek, M.; Bujakowski, W.; Wattor, K.; Tyszer, M. The influence of selected factors on the effectiveness of pre-treatment of geothermal water during the nanofiltration process. Desalination 2017, 406, 74-82. [CrossRef]

24. Tomaszewska, B.; Kmiecik, E.; Wattor, K.; Tyszer, M. Use of numerical modelling in the prediction of membrane scaling. Reaction between antiscalants and feedwater. Desalination 2017, 427, 27-34. [CrossRef]

25. Tomaszewska, B.; Bundschuh, J.; Pajak, L.; Dendys, M.; Delgado Quezada, V.; Bodzek, M.; Armienta, A.A.; Ormachea Munioz, M.; Kasztelewicz, A. Use of low-enthalpy and waste geothermal energy sources to solve arsenic problems in freshwater production in selected regions of Latin America using a process membrane distillation-research into model solutions. Sci. Total Environ. 2020, 714, 136853. [CrossRef]

26. Tomaszewska, B.; Dendys, M. Zero-waste initiatives-Waste geothermal water as a source of medicinal raw material and drinking water. Desalin. Water Treat. 2020, 112, 12-18. [CrossRef]

27. Rusiniak, P.; Wator, K.; Plata, J. Deterministic and probabilistic approaches to the denomination of the hydrochemical type of potentially medicinal groundwater from the "Zdrój Główny" intake (Krzeszowice, Poland). Geol. Geophys. Environ. 2017, 43, 303-309. [CrossRef]

28. Wątor, K.; Kmiecik, E.; Tomaszewska, B. Assessing medicinal qualities of groundwater from the Busko-Zdrój area (Poland) using the probabilistic method. Environ. Earth Sci. 2016, 75, 804. [CrossRef]

29. Wator, K.; Kmiecik, E.; Rusiniak, P. An Influence of Research Methodology on the Results of Determination of a Chemical Composition of Curative Water. Acta Balneologica 2018, 60, 272-276. (In Polish)

30. Wator, K.; Kmiecik, E.; Lipiec, I. The use of principal component analysis for the assessment of the spatial variability of curative waters from the Busko-Zdrój and Solec-Zdrój region (Poland)-preliminary results. Water Supp. 2019, 19, 1137-1143. [CrossRef]

31. RMH. Regulation of the Minister of Health of Poland, of 13 April 2006 on the scope of the studies required to determine the medicinal properties of natural medicinal resources and medicinal properties of climate, the criteria for their evaluation and a specimen certificate confirming these properties. J. Laws 2006. (565).

32. Loos, R.; Marinov, D.; Sanseverino, I.; Napierska, D.; Lettieri, T. Review of the 1st Watch List under the Water Framework Directive and Recommendations for the 2nd Watch List; Publications Office of the European Union: Luxemburg, 2018. 
33. Chowaniec, J. "Hot raw materials" of the Podhale trough (Poland and Slovakia) versus other peri-tatric troughs. Biul. Państw. Inst. Geol. 2012, 448, 229-238. (In Polish)

34. Kepińska, B. The role of the Podhale geothermal system's research for geothermal water exploitation. Tech. Poszuk. Geologicznych Geoterm. Zrównoważony Rozw. 2009, 48, 29-48. (In Polish)

35. Pająk, L.; Tomaszewska, B.; Bujakowski, W.; Bielec, B.; Dendys, M. Review of the Low-Enthalpy Lower Cretaceous Geothermal Energy Resources in Poland as an Environmentally Friendly Source of Heat for Urban District Heating Systems. Energies 2020, 13, 1302. [CrossRef]

36. Kępińska, B.; Ciagło, J. Possibilities of use of the Podhale geothermal waters for balneotherapeutical and recreational purposes. Geologia 2008, 34, 541-559. (In Polish)

37. Sekuła, K. Hydrogeochemical Characteristic of Geothermal Water in Bańska Niżna. Ph.D. Thesis, AGH University of Science and Technology, Kraków, Poland, January 2016.

38. Rusiniak, P.; Ruszczyńska, A.; Wątor, K.; Bulska, E.; Kmiecik, E. Methodological aspects concerning sampling and determination of total selenium and selenium species in geothermal waters. Bull. Geogr. Phys. Geogr. Ser. 2020, 18, 5-16. [CrossRef]

39. ISO. ISO 5667-11:2009—Water Quality—Sampling—Part 11: Guidance on Sampling of Groundwaters; International Organization for Standarization: Geneva, Switzerland, 2009.

40. Kmiecik, E.; Wątor, K.; Tomaszewska, B.; Sekuła, K.; Mika, A. Methodological aspects of pH and EC measurements in geothermal water. Bull. Geogr. Phys. Geogr. Ser. 2020, 17, 39-47. [CrossRef]

41. Zdechlik, R.; Drzymała, M.; Wattor, K. Practical aspects of water sampling in groundwater monitoring. Biul. Państwowego Inst. Geologicznego 2013, 456, 659-664.

42. PN-EN. PN-EN 27888:1999 Water Quality_Determination of Electrical Conductivity; Polish Committee for Standardization: Warsaw, Poland, 1999. (In Polish)

43. ISO. ISO 10523:2008 Water Quality—Determination of $\mathrm{pH}$; International Organization for Standarization: Geneva, Switzerland, 2008.

44. ISO. ISO 11885:2007 Water Quality_Determination of Selected Elements by Inductively Coupled Plasma Optical Emission Spectrometry (ICP-OES); International Organization for Standarization: Geneva, Switzerland, 2007.

45. ISO. ISO 9297:1989 Water Quality-Determination of Chloride-Silver Nitrate Titration with Chromate Indicator (Mohr's Method); International Organization for Standarization: Geneva, Switzerland, 1989.

46. ISO. ISO 9963-1:1994 Water Quality_Determination of Alkalinity_Part 1: Determination of Total and Composite Alkalinity; International Organization for Standarization: Geneva, Switzerland, 1994.

47. ISO. ISO 17294:2016-2 Water Quality-Application of Inductively Coupled Plasma Mass Spectrometry (ICP-MS)_Part 2: Determination of Selected Elements Including Uranium Isotopes; International Organization for Standarization: Geneva, Switzerland, 2016.

48. US Environmental Protection Agency (USEPA). Method 200.7: Trace Elements in Water, Solids, and Biosolids by Inductively Coupled Plasma-Atomic Emission Spectrometry; US Environmental Protection Agency: Washington, DC, USA, 2001.

49. Parkhurst, D.L.; Appelo, C.A.J. Description of Input and Examples for PHREEQC Version 3: A Computer Program for Speciation, Batch-Reaction, ONE-dimensional Transport, and Inverse Geochemical Calculations (No. 6-A43); US Geological Survey: Reston, VA, USA, 2013.

50. Dobrzyński, D.; Kmiecik, E.; Wątor, K. Oxidation Reduction Potential-An Informative and Unused Indicator of Curative and Mineral Water Quality. Acta Balneologica 2018, 60, 233-238.

51. Wator, K.; Dobrzyński, D.; Sugimori, K.; Kmiecik, E. Redox potential research in the field of balneochemistry: Case study on equilibrium approach to bioactive elements in therapeutic waters. Int. J. Biometeorol. 2020, 64, 815-826. [CrossRef] [PubMed]

52. Fallahzadeh, R.A.; Khosravi, R.; Dehdashti, B.; Ghahramani, E.; Omidi, F.; Adli, A.; Miri, M. Spatial distribution variation and probabilistic risk assessment of exposure to chromium in ground water supplies; a case study in the east of Iran. Food Chem. Toxicol. 2018, 115, 260-266. [CrossRef] [PubMed]

53. US Environmental Protection Agency (USEPA). Regional Screening Levels (RSLs)—User's Guide; USEPA: Washington, DC, USA, 2016.

54. Peeters, W.; Peng, Z. An approach towards global standardization of the risk matrix. J. Soc. Sci. Educ. 2015, 2, 31-38. [CrossRef]

55. PN-EN. PN-EN 15975-2:2013-12—Safety of Drinking Water Supply—Crisis Management and Risk GuidelinesPart 2: Risk Management; Polish Committee for Standardization: Warsaw, Poland, 2013. (In Polish) 
56. Bielec, B.; Operacz, A. Newest recognition of exploitation parameters based on Chochołów PIG-1 borehole in the aspect of temperature effect. Inżynieria Ekologiczna 2018, 19, 145-152. [CrossRef]

57. Kmiecik, K.; Korzec, K. Uncertainty associated with the sampling of geothermal water. In Proceedings of the World Geothermal Congress, Melbourne, Australia, 19-25 April 2015.

58. Małecka, D. The thermal waters of Podhale, southern Poland: History of research, genesis and utility. Geol. Q. 2003, 47, 195-210.

59. Mika, A.; Korzec, K. Analysis of the concentration stability of metasilic acid in the thermal water from the Bańska PGP-1 well. Tech. Poszukiwań Geologicznych 2015, 54, 89-96. (In Polish)

60. Operacz, A. Variability of basic geothermal water parameters in Chochołów PIG-1 borehole in the western part of the Podhale Basin. Infrastrukt. Ekol. Teren. Wiej. 2018, 4, 961-972. (In Polish) [CrossRef]

61. GML. Geological and mining law of 9 June 2011. J. Laws 2011. (981) (In Polish)

62. Fleming, J.; Albus, H.; Neidhart, B.; Wegscheider, W. Glossary of analytical terms (VII). Accreditation and Quality Assurance. J. Qual. Comp. Reliab. Chem. Meas. 1997, 2, 51-52.

63. Magnusson, B.; Örnemark, U. (Eds.) Eurachem Guide: The Fitness for Purpose of Analytical Methods-A Laboratory Guide to Method Validation and Related Topics, 2nd ed.; 2014; ISBN 978-91-87461-59-0. Available online: www.eurachem.org (accessed on 7 July 2020).

64. Stefánsson, A.; Arnórsson, S. Gas pressures and redox reactions in geothermal fluids in Iceland. Chem. Geol. 2002, 190, 251-271. [CrossRef]

65. Stefánsson, A.; Arnórsson, S.; Sveinbjörnsdóttir, Á.E. Redox reactions and potentials in natural waters at disequilibrium. Chem. Geol. 2005, 221, 289-311. [CrossRef]

66. Tomaszewska, B.; Bodzek, M. Desalination of geothermal waters using a hybrid UF-RO process. Part I: Boron removal in pilot-scale tests. Desalination 2013, 319, 99-106. [CrossRef]

67. Tomaszewska, B.; Bodzek, M.; Kmiecik, E. Boron removal from geothermal water using DOW chemical high separation BWRO membrane. Desalin. Water Treat. 2016, 57, 27477-27484. [CrossRef]

68. Baba, A.; Şaroğlu, F.; Akkuş, I.; Özel, N.; Yeşilnacar, M.İ.; Nalbantçılar, M.T.; Demir, M.M.; Gökçena, G.; Arslan, S.; Dursun, N.; et al. Geological and hydrogeochemical properties of geothermal systems in the southeastern region of Turkey. Geothermics 2019, 78, 255-271. [CrossRef]

69. Kaasalainen, H.; Stefánsson, A.; Giroud, N.; Arnórsson, S. The geochemistry of trace elements in geothermal fluids, Iceland. Appl. Geochem. 2015, 62, 207-223. [CrossRef]

70. Godgul, G.; Sahu, K.C. Chromium contamination from chromite mine. Environ. Geol. 1995, 25, $251-257$. [CrossRef]

71. Bartlett, R.J.; James, B.R. Mobility and bioavailability of chromium in soils. In Chromium in the Natural and Human Environments; Jerome, O., Ed.; Wiley: New York NY, USA, 1988; Volume 20, pp. 267-304.

72. Kasassi, A.; Rakimbei, P.; Karagiannidis, A.; Zabaniotou, A.; Tsiouvaras, K.; Nastis, A.; Tzafeiropoulou, K. Soil contamination by heavy metals: Measurements from a closed unlined landfill. Bioresour. Technol. 2008, 99, 8578-8584. [CrossRef]

73. Gowd, S.S.; Reddy, M.R.; Govil, P.K. Assessment of heavy metal contamination in soils at Jajmau (Kanpur) and Unnao industrial areas of the Ganga Plain, Uttar Pradesh, India. J. Hazard. Mater. 2010, 174, 113-121. [CrossRef]

74. Ye, T.; Li, H.; Wang, Z.X.; Huang, R.; Yu, Y.J.; Yang, Z.; Gao, C.; Xie, C. Transport and fate of hexavalent chromium in slag-soil system. Environ. Earth Sci. 2019, 78, 239. [CrossRef]

75. Pađan, J.; Marcinek, S.; Cindrić, A.M.; Layglon, N.; Lenoble, V.; Salaün, P.; Garnier, C.; Omanović, D. Improved voltammetric methodology for chromium redox speciation in estuarine waters. Anal. Chim. Acta 2019, 1089, 40-47. [CrossRef] [PubMed]

76. Wu, B.; Zhang, Y.; Zhang, X.X.; Cheng, S.P. Health risk assessment of polycyclic aromatic hydrocarbons in the source water and drinking water of China: Quantitative analysis based on published monitoring data. Sci. Total Environ. 2011, 410, 112-118. [CrossRef] [PubMed]

77. Williams, P.R.; Scott, P.K.; Sheehan, P.J.; Paustenbach, D.J. A probabilistic assessment of household exposures to MTBE from drinking water. Hum. Ecol. Risk Assess. 2000, 6, 827-849. [CrossRef]

78. Huang, D.; Yang, J.; Wei, X.; Qin, J.; Ou, S.; Zhang, Z.; Zou, Y. Probabilistic risk assessment of Chinese residents' exposure to fluoride in improved drinking water in endemic fluorosis areas. Environ. Pollut. 2017, 222, 118-125. [CrossRef] 
79. Leung, A.O.; Duzgoren-Aydin, N.S.; Cheung, K.C.; Wong, M.H. Heavy metals concentrations of surface dust from e-waste recycling and its human health implications in southeast China. Environ. Sci. Technol. 2008, 42, 2674-2680. [CrossRef]

80. Sharma, S.; Nagpal, A.K.; Kaur, I. Appraisal of heavy metal contents in groundwater and associated health hazards posed to human population of Ropar wetland, Punjab, India and its environs. Chemosphere 2019, 227, 179-190. [CrossRef]

81. Zhang, Y.; Chen, J.; Shi, W.; Zhang, D.; Zhu, T.; Li, X. Establishing a human health risk assessment methodology for metal species and its application of $\mathrm{Cr}^{6+}$ in groundwater environments. Chemosphere 2017, 189, 525-537. [CrossRef]

82. Magesh, N.S.; Chandrasekar, N.; Elango, L. Trace element concentrations in the groundwater of the Tamiraparani river basin, South India: Insights from human health risk and multivariate statistical techniques. Chemosphere 2017, 185, 468-479. [CrossRef]

83. Tseng, C.H.; Lee, I.H.; Chen, Y.C. Evaluation of hexavalent chromium concentration in water and its health risk with a system dynamics model. Sci. Total Environ. 2019, 669, 103-111. [CrossRef]

84. Wen, X.; Lu, J.; Wu, J.; Lin, Y.; Luo, Y. Influence of coastal groundwater salinization on the distribution and risks of heavy metals. Sci. Total Environ. 2019, 652, 267-277. [CrossRef] [PubMed]

85. Fryer, M.; Collins, C.D.; Ferrier, H.; Colvile, R.N.; Nieuwenhuijsen, M.J. Human exposure modelling for chemical risk assessment: A review of current approaches and research and policy implications. Environ. Sci. Policy 2006, 9, 261-274. [CrossRef]

86. Gao, J.; Liu, Q.; Song, L.; Shi, B. Risk assessment of heavy metals in pipe scales and loose deposits formed in drinking water distribution systems. Sci. Total Environ. 2019, 652, 1387-1395. [CrossRef] [PubMed]

87. Kavcar, P.; Sofuoglu, A.; Sofuoglu, S.C. A health risk assessment for exposure to trace metals via drinking water ingestion pathway. Int. J. Hyg. Environ. Health 2009, 212, 216-227. [CrossRef]

88. Yin, J.; Wang, L.; Chen, Y.; Zhang, D.; Hegazy, A.M.; Zhang, X. A comparison of accumulation and depuration effect of dissolved hexavalent chromium $\left(\mathrm{Cr}^{6+}\right)$ in head and muscle of bighead carp (Aristichthys nobilis) and assessment of the potential health risk for consumers. Food Chem. 2019, 286, 388-394. [CrossRef]

89. Shakeri, A.; Fard, M.S.; Mehrabi, B.; Mehr, M.R. Occurrence, origin and health risk of arsenic and potentially toxic elements (PTEs) in sediments and fish tissues from the geothermal area of the Khiav River, Ardebil Province (NW Iran). J. Geochem. Explor. 2020, 208, 106347. [CrossRef]

90. Bonmatin, J.M.; Noome, D.A.; Moreno, H.; Mitchell, E.A.; Glauser, G.; Soumana, O.S.; Bijleveld van Lexmond, M.; Sánchez-Bayo, F. A survey and risk assessment of neonicotinoids in water, soil and sediments of Belize. Environ. Pollut. 2019, 249, 949-958. [CrossRef]

91. Buchner, E.M.; Happel, O.; Schmidt, C.K.; Scheurer, M.; Schmutz, B.; Kramer, M.; Knauer, M.; Gartiser, S.; Hollert, H. Approach for analytical characterization and toxicological assessment of ozonation products in drinking water on the example of acesulfame. Water Res. 2019, 153, 357-368. [CrossRef]

92. Cheng, M.; Liu, T.K.; Olenin, S.; Su, P.X. Risk assessment model based on expert's perspective for ballast water management. Ocean Coast. Manag. 2019, 171, 80-86. [CrossRef]

93. Domínguez, C.R.; Martínez, I.V.; Peña, P.M.P.; Ochoa, A.R. Analysis and evaluation of risks in underground mining using the decision matrix risk-assessment (DMRA) technique, in Guanajuato, Mexico. J. Sustain. Min. 2019, 18, 52-59. [CrossRef]

94. Faber, J.H.; Marshall, S.; Van den Brink, P.J.; Maltby, L. Priorities and opportunities in the application of the ecosystem services concept in risk assessment for chemicals in the environment. Sci. Total Environ. 2019, 651, 1067-1077. [CrossRef] [PubMed]

95. Gul, M.; Guneri, A.F. A fuzzy multi criteria risk assessment based on decision matrix technique: A case study for aluminum industry. J. Loss Prevent. Proc. 2016, 40, 89-100. [CrossRef]

96. Guo, X.; Feng, C.; Gu, E.; Tian, C.; Shen, Z. Spatial distribution, source apportionment and risk assessment of antibiotics in the surface water and sediments of the Yangtze Estuary. Sci. Total Environ. 2019, 671, 548-557. [CrossRef]

97. Matthes, C.S.; Woerner, D.F.; Hendricks, T.J. Risk management for dynamic Radioisotope Power Systems. J. Soc. Sci. Environ. 2018, 5, 3-8. [CrossRef]

98. Mohtar, W.H.M.W.; Maulud, K.N.A.; Muhammad, N.S.; Sharil, S.; Yaseen, Z.M. Spatial and temporal risk quotient based river assessment for water resources management. Environ. Pollut. 2019, 248, $133-144$. [CrossRef] 
99. Moss, S.; Ulber, L.; den Hoed, I. A herbicide resistance risk matrix. Crop. Prot. 2019, 115, 13-19. [CrossRef]

100. Praveena, S.M.; Shaifuddin, S.N.M.; Sukiman, S.; Nasir, F.A.M.; Hanafi, Z.; Kamarudin, N.; Ismail, T.H.T.; Aris, A.Z. Pharmaceuticals residues in selected tropical surface water bodies from Selangor (Malaysia): Occurrence and potential risk assessments. Sci. Total Environ. 2018, 642, 230-240. [CrossRef]

101. Schaefer, T.; Udenio, M.; Quinn, S.; Fransoo, J.C. Water risk assessment in supply chains. J. Clean. Prod. 2019, 208, 636-648. [CrossRef]

102. Xiao, J.; Wang, L.; Deng, L.; Jin, Z. Characteristics, sources, water quality and health risk assessment of trace elements in river water and well water in the Chinese Loess Plateau. Sci. Total Environ. 2019, 650, 2004-2012. [CrossRef]

103. Jeleński, T.; Dendys, M.; Tomaszewska, B.; Pająk, L. The potential of RES in the reduction of air pollution: The SWOT analysis of smart energy management solutions for Krakow Functional Area (KrOF). Energies 2020, 13, 1754. [CrossRef]

104. Benekos, I.D.; Shoemaker, C.A.; Stedinger, J.R. Probabilistic risk and uncertainty analysis for bioremediation of four chlorinated ethenes in groundwater. Stoch. Environ. Res. Risk 2007, A21, 375-390. [CrossRef]

105. Rezaei, A.; Hassani, H.; Hayati, M.; Jabbari, N.; Barzegar, R. Risk assessment and ranking of heavy metals concentration in Iran's Rayen groundwater basin using linear assignment method. Stoch. Environ. Res. Risk 2018, A32, 1317-1336. [CrossRef]

(C) 2020 by the authors. Licensee MDPI, Basel, Switzerland. This article is an open access article distributed under the terms and conditions of the Creative Commons Attribution (CC BY) license (http://creativecommons.org/licenses/by/4.0/). 